\title{
Influences of wave fetch, tidal flow and ocean colour on subtidal rocky communities
}

\author{
Michael T. Burrows* \\ Department of Ecology, Scottish Association for Marine Science, Scottish Marine Institute, Oban, Argyll, PA37 1QA, UK
}

\begin{abstract}
Community assemblages on subtidal rock change markedly along gradients of wave energy, tidal flow, and turbidity. The importance of these assemblages for rare and delicate species, for shellfish, as nursery areas for fish, and for their contribution to ecosystem functioning in coastal areas has prompted much conservation effort in many countries. I applied a rapid method of calculating a large high-resolution (200 m scale) map of wave exposure $<5 \mathrm{~km}$ from the UK coastline to compare with UK subtidal biodiversity records from diver surveys from the 1970s to the 2000s. Satellite-derived estimates of ocean colour, and tidal flows from hydrodynamic models were also extracted for each site. Ordinal logistic regression of categorical abundance data gave species-distribution patterns with wave fetch and depth and dependence on chlorophyll and tidal flows: macroalgae declined with increasing chlorophyll and increased with tidal flow. Multivariate community analysis showed shifts from algae to suspension-feeding animals with increasing depth and in areas of high chlorophyll and tidal flow and a change from delicate forms in waveshelter to robust species at wave-exposed sites. The strongest positive influence on species diversity was found to be the presence of the kelp Laminaria hyperborea: sites with $0 \%$ cover had a median of 6 species, while those with $>40 \%$ cover had a median of 22 species. Laminaria hyperborea, and the most diverse communities, is found in areas of estimated low chlorophyll concentrations and in the most wave-exposed environments, which are often but not always in areas of high tidal flow.
\end{abstract}

KEY WORDS: Wave fetch $\cdot$ Wave exposure $\cdot$ Subtidal rock $\cdot$ Community structure

\section{INTRODUCTION}

At a time of growing human pressures on coasts, there is a pressing need to understand and predict the spatial distribution of coastal biodiversity and biological resources and to balance conservation and exploitation objectives, especially in the context of marine spatial planning. Conservation and ecosystem-based management should take account of the contribution of coastal habitats to the functioning of the coastal marine ecosystem (Crowder \& Norse 2008). The need for good information on the distribution of habitats and species has long been recognised and much data already exists, yet the information contained in this data is not fully exploited. Better understanding of relationships of species and communities with environmental variables will allow better prediction of where valued species and habitats may be found, and thereby where human impacts may be most harmful. Mapping biological resources through the development of statistical models that link abundance to environmental predictors can fulfill many of these needs. The present study aims to address this need for shallow $(<50 \mathrm{~m})$, subtidal rock communities in the northeast Atlantic.

On rocky coasts, wave exposure has long been identified as a major influence on the local distribution of species and communities, particularly in the intertidal zone (e.g. Cotton 1909, Lewis 1964). Mechanical impact from passing breaking waves can 
present both problems and opportunities for a wide variety of marine organisms, and the biomechanical implications for living in a wave-beaten environment are relatively well understood (Denny 1988). Direct negative effects are on the structural integrity of attached animals and plants being torn apart by drag forces (Friedland \& Denny 1995), broken through repeated flexing (Mach et al. 2007) or smashed by wave-borne debris (Shanks \& Wright 1986), and on the ability of mobile species or settling stages to remain attached to the rock (Vadas et al. 1990). Positive effects of waves are harder to find, but waveinduced water flow can increase the supply of (1) food to suspension feeders, and thence enhances growth rate (Burrows et al. 2010); (2) larvae to the rock surface and thence enhances settlement rate (Burrows et al. 2010); and (3) nutrients to growing algae (Dayton 1985). (4) At the community level, increased environmental stress in extreme wave exposure may give tolerant species a refuge from competition and predation (Menge \& Sutherland 1987). Varying exposure to different levels of wave flow can result in changes in growth forms that help adapt to life in fast-moving water. Animals grow more robust shells and devote more resources to attachment (Crothers 1983), while plants may change frond morphology to reduce drag (Sjøtun \& Fredriksen 1995). Translating and summing species-level effects to influences on species assemblages and interactions gives the familiar shifts in communities seen along wave exposure gradients (Burrows et al. 2008) and contributes to performance-driven changes in community regulation (Menge \& Sutherland 1987).

Field ecologists have for decades recognised the importance of categorising sites for wave exposure to provide context for experimental studies and for classifying sites for management and conservation objectives (Hiscock 1996). Categorisation can be informally based on perceived physical characteristics of a site, either before a visit by consulting a map or from observed wave-wash. Formal classification schemes are usually based on wave fetch, the distance over which wind-driven waves can build, or on a combination of fetch and diagnostic assemblages of species applicable to the region (Ballantine 1961). Numerical wave exposure indices, or model-based estimates of wave height, offer a viable and objective alternative to such classification schemes and offer operator-independent measures that are widely comparable. Simple indices are based on the number of angular sectors open to waves (the 'Baardseth Index'; Baardseth
1970). More complex indices are based on the summed distance to the nearest land in angular sectors, weighted by incidence and speeds of wind in those sectors, and can be modified by the presence of shallow water close inshore (Thomas 1986) and wave refraction effects (Bekkby et al. 2008).

The development of geographical information systems (GIS) and the ready availability of computing power have made automated calculation of numerical wave exposure indices feasible and desirable. While such indices remain a substitute for estimates of wave climate, as can be delivered by physical models (Booij et al. 1999) and direct or indirect measurements (Jones \& Demetropoulos 1968, Friedland \& Denny 1995), they have real value as predictors of the structure of biological communities (Burrows et al. 2008), effects of wave action on single species (Isaeus 2004) and the outcome of interactions (Jonsson et al. 2006).

Automated methods obtain numerical wave exposure indices by determining wave fetch in angular sectors around focal points by grid-based searches for nearby land (Isaeus 2004, Bekkby et al. 2008, Burrows et al. 2008) or by detecting line-crossing by vector coastlines (Davies \& Johnson 2006, Pepper \& Puotinen 2009). The grid-search method allows very rapid calculation of fetch indices for a large number of cells, enabling very high resolution maps of wave fetch to be produced (10 m grid; Bekkby et al. 2009). I used a grid-search approach in the present study to produce a wave fetch map for inshore areas $(<5 \mathrm{~km})$ of the entire UK coast, giving $1.9 \times 10^{6}$ fetch values in a grid of $40.1 \times 10^{6}$ cells, each $200 \times 200 \mathrm{~m}(1185 \times$ $1538 \mathrm{~km})$. More complex indices were not attempted for several reasons. Compound indices including local wind climate or attenuation with depth have so far proved to add little to the predictive power of these indices (Burrows et al. 2008, Bekkby et al. 2009). Synoptic wind data can be difficult to obtain, and the effects of wind flows over complex landforms can make the translation from meteorological station data to wind fields difficult at the scale relevant to fetch models. Wind velocity and wave fetch may covary: exposed coasts have higher average wind velocities. Not compounding other influences, such as depth, into complex indices allows examination of these effects independently from wave action. Finally, the simplicity of a coastline-only index allows the approach to be applied wherever digital coastline data exists.

The aims of the present study were (1) to develop a simple grid-based approach to mapping wave fetch over large areas at high resolution; (2) to use 

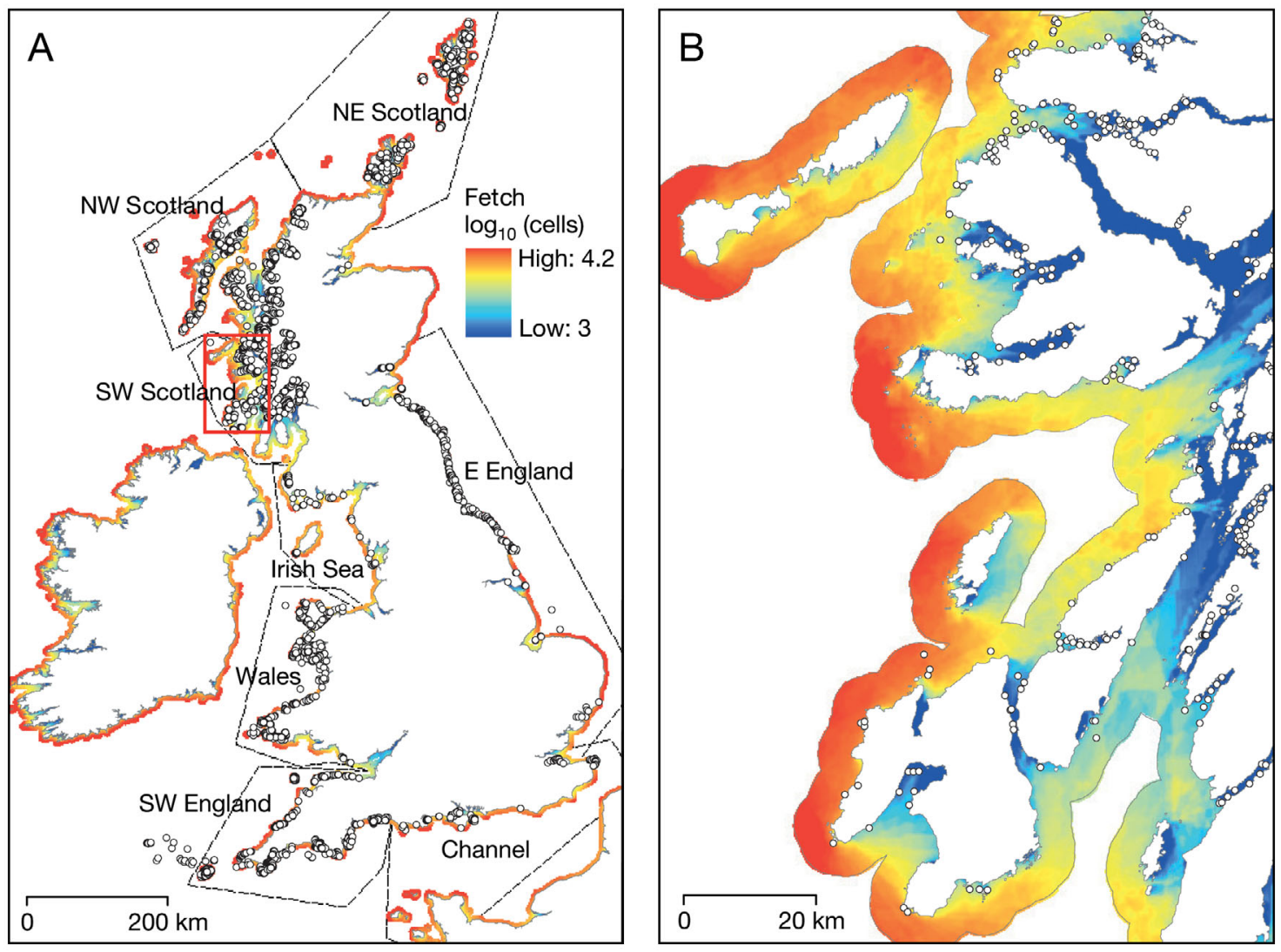

Fig. 1. (A) Extent of the study area and division into eight regions. (B) Detail of patterns of wave fetch near Oban on the west coast of Scotland (red box in Panel A), showing the $5 \mathrm{~km}$ offshore limit of the model. O: Marine Nature Conservation Review survey sites (Hiscock 1996)

this data to assign wave-fetch values to existing biodiversity records over a large geographical region and combine this with other synoptic data, including remotely sensed chlorophyll concentrations and model-predicted tidal flow rates; and (3) to use statistical regression techniques to determine the relative influences of local, site-specific effects (wave action), and larger scale, regionally variable influences (ocean colour, tidal flow, expressed as energy per unit area) on the structure and composition of subtidal rock communities. The biodiversity records used here come from the UK Marine Nature Conservation Review (MNCR; Hiscock 1996), a survey of the entire subtidal rocky coastline of the UK made between 1980-2000 covering a wide geographical range of environmental conditions. Many of the general trends in the data are already known (Hiscock 1985), such as the restriction of kelp communities to shallow depths in water of greater light attenuation (Kain 1977), but no systematic approach to model these trends has yet been attempted.

\section{MATERIALS AND METHODS}

\section{Calculation of wave fetch}

I used a modified version of the method of Burrows et al. (2008) to produce a map of near-coastal $(<5 \mathrm{~km})$ wave exposure for the UK, based on total wave fetch as the distance to the nearest land around each point on the map. A digital vector coastline dataset (GSHHS, NOAA 2007) was rasterised in a GIS (ArcGIS 9.2) to produce a $200 \mathrm{~m}$ cell grid of the coastline, with each cell attributed to land or sea. A $5 \mathrm{~km}$ buffer from the coast delineated the nearshore model domain, and was chosen to encompass most of the shallow subtidal study sites and keep model computation down to a reasonable time $(\sim 5 \mathrm{~h}$ for a $2 \mathrm{GHz}$ PC processor). The extent of the grid map (Fig. 1) was chosen to allow determination of fetch for up to $200 \mathrm{~km}$ away from the areas of interest. $200 \mathrm{~km}$ approximates to the 'transition point' for northern UK waters (Burrows et al. 2008), where the distance that the wind blows over the sea is considered sufficiently 
long for wave conditions to be fully developed (Harborne et al. 2006).

The distance to the nearest land was determined in $32\left(11.25^{\circ}\right)$ angular sectors for each $200 \mathrm{~m}$ grid cell in the model domain. This was achieved by successively scanning the surrounding area for land at 3 scales: every 100 cells up to 1000 cells distant $(200 \mathrm{~km})$, every 10 cells up to 100 cells distant, and every cell up to 10 cells away. If the distance from the focal cell was less than the previously recorded minimum in that $11.25^{\circ}$ sector, this distance became the new minimum distance for that sector. The final fetch value for each cell was the sum of the fetch values over all 32 sectors, expressed variously as the number of cells, distance in $\mathrm{km}$ or as $\log _{10}$ of the number of cells (Fig. 1). This gave ranges of values from 0 to 32000 cells, 0 to $6400 \mathrm{~km}$, and $\log _{10}$ (cells) 0 to 4.5; the latter units were used throughout subsequent analyses. Irregularities introduced as artefacts from this reduced sampling scheme, such as islands small enough to be missed in one cell yet detected as nearby land in an adjacent cell, were minimised by averaging fetch values over a $3 \times 3$ area centred on each cell.

The area modelled for wave fetch extended across the entire UK (Fig. 1; OSGB National Grid coordinates: bottom left $-325000,485000$ to top right 725000,$1305000 ; 53.7527^{\circ} \mathrm{N}, 13.0175^{\circ} \mathrm{W}$ to $\left.61.4890^{\circ} \mathrm{N}, 4.1075^{\circ} \mathrm{E}\right)$.

\section{Subtidal rock community surveys}

The MNCR was a UK-based project designed to assess marine habitats and species for management of coastal zones and the open sea. The project used standardised methodologies (Hiscock 1996) for recording abundance and extent of species and habitats. For this study, I used the publicly available species records from MNCR surveys of UK sublittoral habitats, downloaded from the National Biodiversity Network gateway (NBN 2006). Fifty-two species were selected for download and analysis as those occurring in $>5 \%$ of records associated with infralittoral and circalittoral habitats and with kelp biotope complexes (Birkett et al. 1998, Connor et al. 2004; see Table S2 in the supplement at www.int-res.com/ articles/suppl/m445p193_supp.pdf). Single-species datafiles from NBN were reassembled into a species by survey data matrix by matching records by date, location and depth. A total of 5959 surveys at 3307 distinct sites lay within the wave fetch model domain and were further analysed. These surveys covered a period from 1977 to 1999 , with $9 \%$ in the 1970 s, $48 \%$ in the 1980s, and $42 \%$ in the 1990s. Sites were assigned to 6 regions (Fig. 1): SW England (including Channel sites), Irish Sea (including Wales), SW Scotland, NW Scotland, NE Scotland (including Orkney and Shetland), and E England.

Sublittoral rock habitats were surveyed using SCUBA diving (Connor \& Hiscock 1996). Divers swam along a transect assessing the abundance of species over an extended area of habitat within a recorded depth range, assumed to be along a line spanning $<200 \mathrm{~m}$ of habitat given the time limitation of a single SCUBA dive. Species abundance was estimated as population density or percentage cover, then recorded as a categorical abundance value on the MNCR SACFOR scale (Superabundant, Abundant, Common, Frequent, Occasional and Rare; Table S1 in the supplement) (Connor et al. 2004). Surveys were generally completed in a day, with several dives over different depth ranges at each location. Absences of species were not recorded: no distinction could be made between true absence (not seen, a true negative) and a lack of a positive record (false negative). All negative records were treated as absences in further analyses. Abundance data were collected from surveys over more than 1 depth range at $43 \%$ of the 3307 sites, with $10 \%$ over 3 or more depth ranges. Species data were aggregated at site level by recording maximum abundance across all depth ranges surveyed and species diversity as the total number of species recorded at the site.

\section{Tidal power and ocean colour}

Tidal power data was obtained from the UK Atlas of Marine Renewable Energy Resources (BERR 2008). The data were derived from a $1.8 \mathrm{~km}$ resolution depth-stratified model (Proudman Oceanographic Laboratory High Resolution Continental Shelf model, ABP Marine Environmental Research 2008). Values used were depth-averaged tidal power $\left(P\right.$ in $\mathrm{kW} \mathrm{m}^{-2}$, where $P=0.5 \rho U^{3}, \rho$ is density and $U \mathrm{i}$ current velocity; Fig. 2A). Optical properties of seawater around the UK were derived from satellite images and expressed as estimated chlorophyll a concentrations ( $\mathrm{chl} \mathrm{a}$ ) in $\mathrm{mg} \mathrm{m}^{-3}$. Data were obtained from the NASA Giovanni data portal and were from the MODIS Aqua satellite, expressed as $9 \mathrm{~km}$ resolution, time-averaged from monthly values from December 2002 to December 2008 (NASA 2009; Fig. 2B). Assignment of values to coastal survey sites 

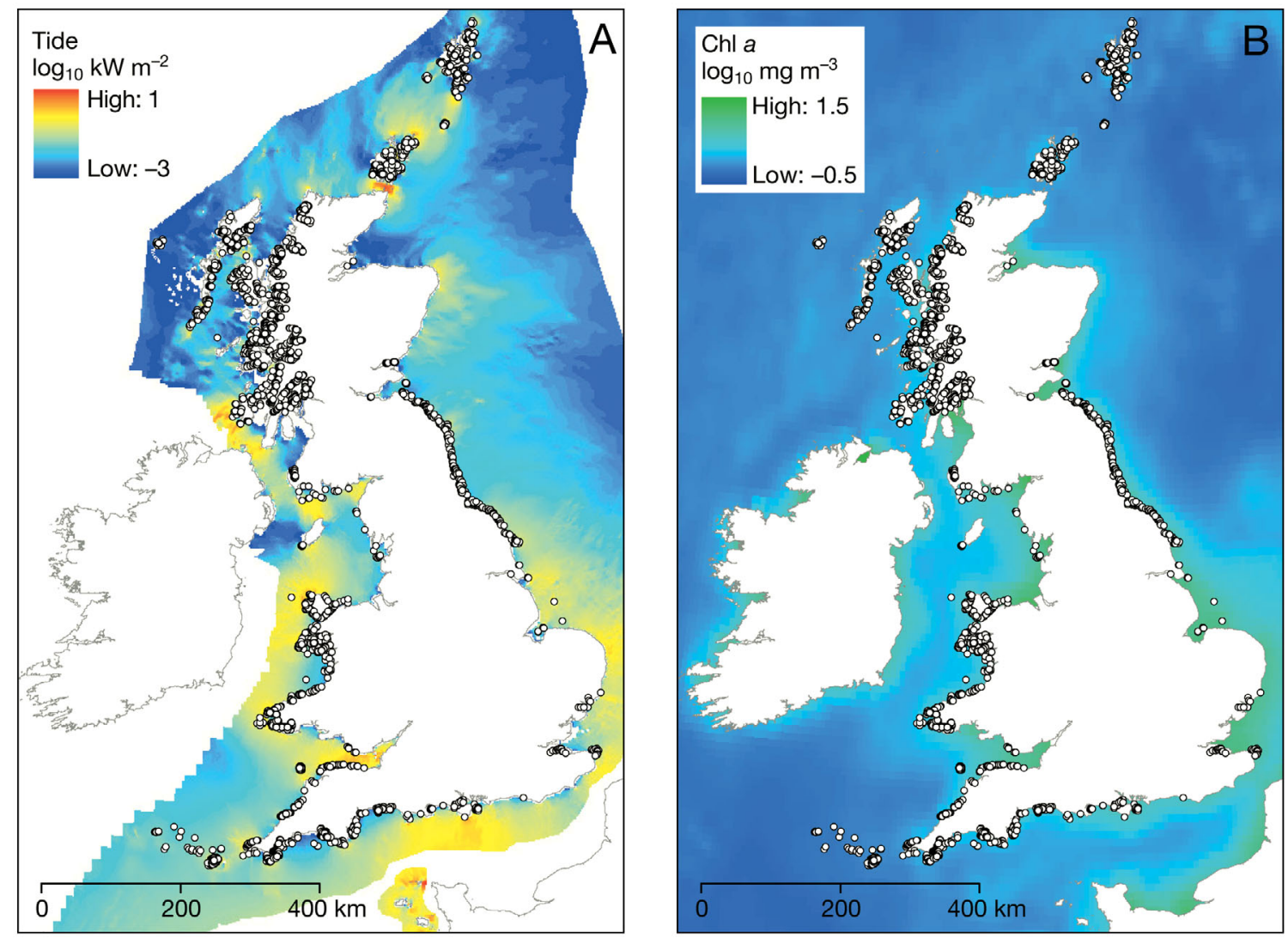

Fig. 2. Patterns of (A) tidal power ( $\log _{10} \mathrm{~kW} \mathrm{~m}^{-2}$, from a $1.8 \mathrm{~km}$ resolution depth-stratified model) and (B) chl a concentrations $\left(\log _{10} \mathrm{mg} \mathrm{m}^{-3}\right.$ from MODIS Aqua satellite data, $9 \mathrm{~km}$ average for 2002 to 2008) around the UK

that were otherwise masked from satellite data or not included in the tide model domain was enabled by averaging grids over rectangular neighbourhoods of $5 \times 5 \mathrm{~km}$ for tide and $27 \times 27 \mathrm{~km}$ for $\mathrm{chl} a$.

\section{Statistical analyses}

I analysed the responses of each species to depth, wave fetch, tidal power and chl a by using these as predictors in ordinal logistic regression models (SAS PROC GENMOD with a cumulative logit link function; SAS Institute 2004). This approach modelled the probability that abundance reached at least a particular SACFOR category. Wave fetch, tidal power and chl a values for survey sites were obtained by matching locations to grid cells using a GIS. Survey depth was taken as the middle of the reported depth range. Wave fetch was classed into $0.5 \log _{10}$ cell intervals, and depth was classed into $5 \mathrm{~m}$ intervals, while tidal power and chl a were treated as interacting linear predictors. Effect sizes were reported as the change in $\log$ odds ratios, i.e. the logarithm of the odds $p /(1-p)$ (where $p$ is the probability of reaching at least a particular abundance category), per unit chl a or tidal power. I also analysed multivariate community responses to these factors using principal components analysis (PCA) on the species-sites matrix of abundance values. Categorical (SACFOR) abundance data was converted to numeric data by assigning integer values to each category, combining the top 2 categories ( $\mathrm{S}$ and $\mathrm{A}$ ) into a single class (5). Scores for each site were stored for the first 4 principal components extracted by the analysis. The number of species with non-zero abundance was also calculated for each survey.

Patterns of community structure were analysed by a hierarchy of increasingly complex ANOVAs for each PCA score (see Table 1): M1 including main effects of survey depth, wave fetch and their interaction; M2 further including survey region and interactions between depth, fetch and region; M3 adding tide and chl $a$ as covariates; and M4 adding interactions between tide, chl $a$ and depth and wave 
Table 1. Variance estimates and $\mathrm{R}^{2}$ from ANOVAs of principal component scores with categorised wave fetch and depths across 6 study regions, and with chl a $\left(\log _{10} \mathrm{mg} \mathrm{m}^{-3}\right)$ and estimated tidal power $\left(\log _{10} \mathrm{~kW} \mathrm{~m}^{-2}\right)$. Error df and overall model $\mathrm{R}^{2}$ are also shown. Models (M5, see 'Materials and methods: Statistical analysis') were produced by eliminating nonsignificant terms from the full model including all interaction terms (which was always the lowest $\mathrm{AIC}_{\mathrm{C}}$ model when compared with models with and without region effects and with and without tide and chl $a$ as covariates). All p-values for $F$-ratios were $<0.01$ for the terms remaining in the reduced model

\begin{tabular}{|c|c|c|c|c|c|c|c|c|c|}
\hline Source & $\mathrm{df}$ & PCA1 & PCA2 & PCA3 & Source & df & PCA1 & PCA2 & PCA3 \\
\hline Depth & 4 & 18.8 & 36.8 & 18.1 & Chl a & 1 & 9.3 & 11.9 & 10.6 \\
\hline Fetch & 5 & 14.9 & 4.9 & 18.3 & Tide & 1 & & 9.1 & 0.2 \\
\hline Depth $\times$ Fetch & 20 & 1.6 & 4.8 & 5.9 & Chl $a \times$ Tide & 1 & & 10.3 & 14.9 \\
\hline Region & 5 & 23.2 & 26.7 & 20.5 & Chl $a \times$ Depth & 4 & 2.9 & & 3.1 \\
\hline Depth $\times$ Region & 20 & 3.4 & 3 & 4.3 & Chl $a \times$ Fetch & 5 & 4.8 & & 5.2 \\
\hline \multirow[t]{2}{*}{ Fetch $\times$ Region } & 24 & 2.8 & 4.3 & 9.8 & Tide $\times$ Depth & 4 & & & 10.2 \\
\hline & & & & & Tide $\times$ Fetch & 5 & & & \\
\hline $\mathrm{R}^{2}$ & & 0.23 & 0.36 & 0.31 & & & & & \\
\hline \multicolumn{5}{|c|}{ Regression coefficients, $b$} & \multicolumn{5}{|c|}{ Standardised regression coefficients, $b^{\prime}\left(=b \times s_{X} / s_{Y}\right)$} \\
\hline Chl a & & \multirow[t]{3}{*}{$-1.06^{* * *}$} & $0.54^{* * *}$ & $0.35^{\mathrm{ns}}$ & & & \multirow{3}{*}{-0.29} & 0.15 & 0.1 \\
\hline Tide & & & $-0.06^{* * *}$ & $0.1^{* * *}$ & & & & -0.09 & 0.15 \\
\hline Chl $a \times$ Tide & & & $0.17^{* * *}$ & $0.27^{* * *}$ & & & & 0.12 & 0.2 \\
\hline
\end{tabular}

fetch. Survey depths were classed into $5 \mathrm{~m}$ bins from 0 to $20 \mathrm{~m}$, then a single depth bin for $>20 \mathrm{~m}$. Wave fetch as $\log _{10}$ cells (multiples of $200 \mathrm{~m}$ ) was classed into six $0.5 \log$ intervals from 1.5 to 4.0 , equivalent to class divisions of 6.3,20,63, 200, 632 and $2000 \mathrm{~km}$ total distance over 32 angular sectors.

Akaike's Information Criterion corrected for sample size $\left(\mathrm{AIC}_{\mathrm{c}}\right)$ were used to select the best of models M1 to M4 for each PCA score. For PCA1 and PCA3 the most complex model (M4) was the best, with M3 the best for PCA2. Non-significant higher order interactions were removed from this complex model to produce a final model, M5, shown in Table 1. Given the large sample sizes (Table S3 in the supplement), the central limit theorem applies (Sokal \& Rohlf 1996), and non-normality of the data was not expected to cause problems with hypothesis testing. Therefore, no data transformations were considered necessary. The potential issue of spatial non-independence of data did not prove to be a problem. Residual values from fitted models (M5) were not correlated at small spatial scales $(<20 \mathrm{~km}, \mathrm{r}<0.1)$.

The direct and indirect effects of wave fetch, chl $a$ and tidal power on the abundance of the kelp Laminaria hyperborea and species diversity were evaluated by fitting a structural equation model (using AMOS 5.0; Shipley 2000, Arbuckle 2005) to site data. Kelp abundance was expressed at the site level as the maximum recorded over all depths surveyed.

\section{RESULTS}

The wave fetch model produced large-scale geographical (Fig. 1A), and small-scale local (Fig. 1B), patterns of wave fetch that were in line with expectations. Open oceanic coastlines tended to have high values ( $>3.5)$ and sheltered sea lochs tended to have low values $(<2)$, while islands and promontories produced low values in their lee. Areas of high tidal power (Fig. 2A) around the UK tend to occur where flow is restricted, for example, around Orkney at the edge of the North Sea and off southwest Scotland where the Irish Sea meets the ocean. The lowest calculated coastal chl a values (Fig. 2B) are found furthest from major centres of population, in northwest Scotland and southwest England, and away from areas of high levels of suspended sediments, such as the Bristol Channel and the southern North Sea.

\section{Species responses to wave fetch, depth, tidal power and chlorophyll a}

Most species were unequally distributed among depth and wave fetch classes, and many were significantly affected by chl $a$, tidal flow and the interaction between these 2 factors (Fig. 3 for selected species, Fig. S1 in the supplement at www.intres.com/articles/suppl/m445p193_supp.pdf for all species distributions with depth and wave fetch). 

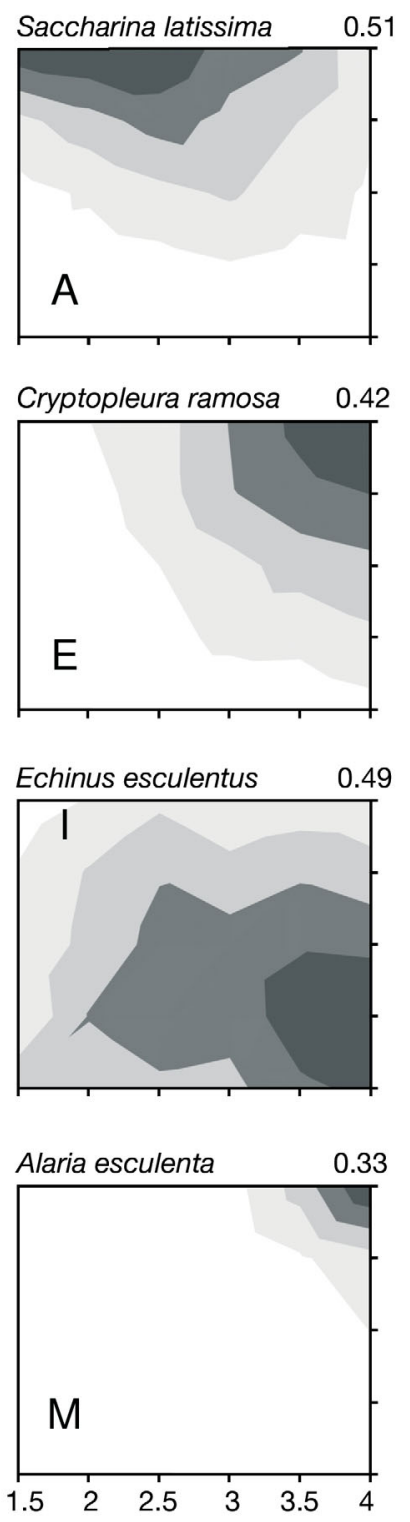

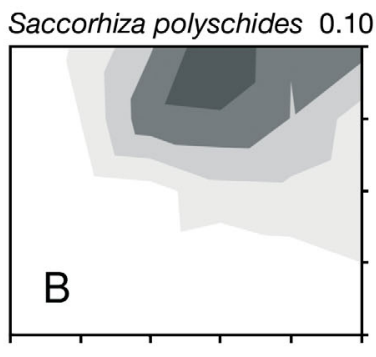

Plocamium cartilagineum 0.54
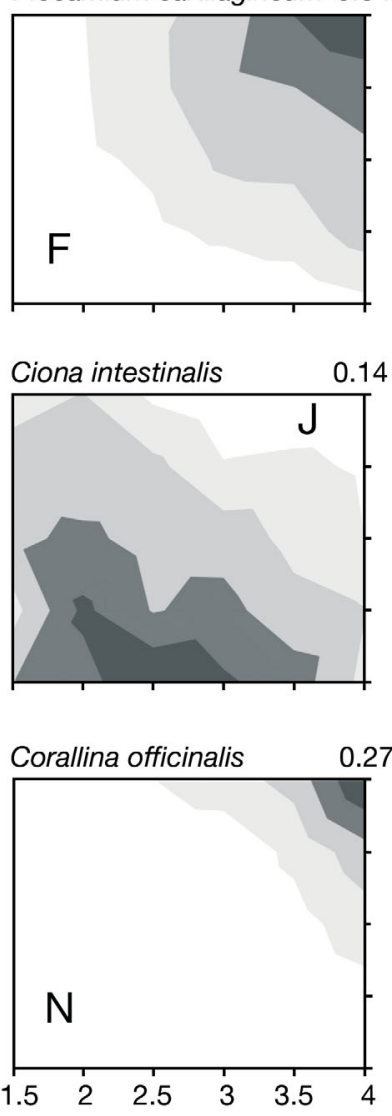
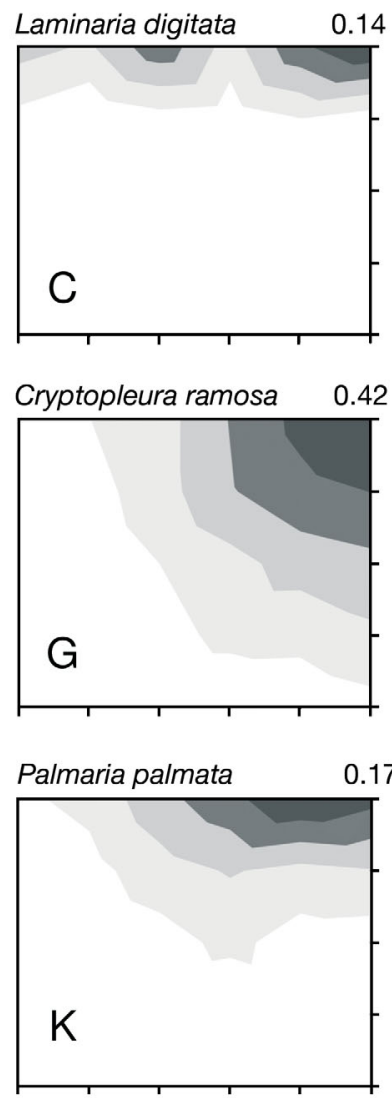

0.17
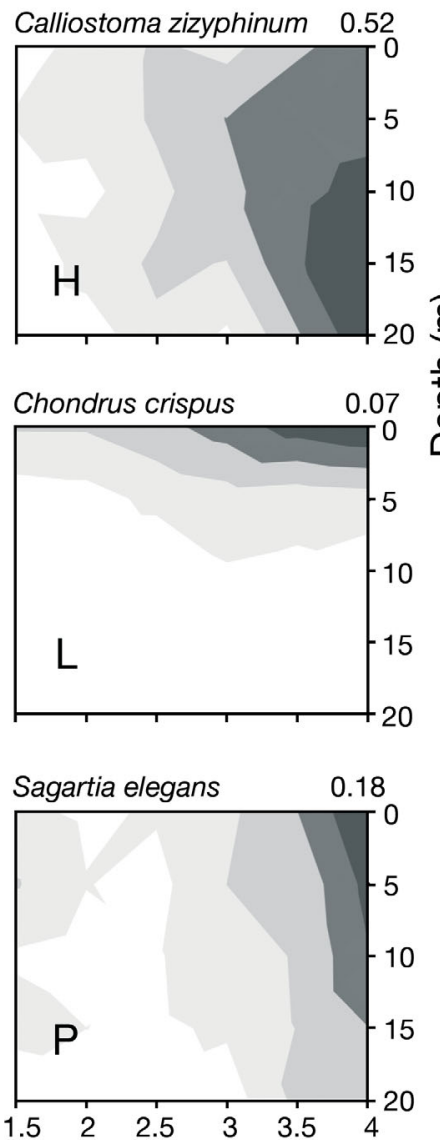

Wave fetch $\left(\log _{10}\right.$ cells)

Fig. 3. Distributions of selected species on gradients of wave fetch and depth of surveys. Plots show the predicted probability of a species being Common, Abundant or Superabundant (see Table S1 for definitions of abundance categories and Fig. S1 for a fuller set of species in the supplement at www.int-res.com/articles/suppl/m445p193_supp.pdf) from ordinal logistic regression of abundance categories against wave fetch and depth classes. Responses are scaled in $20 \%$ classes between 0 (white) and $100 \%$ (dark grey) of the maximum probability (shown at top right of each panel). (A-D) Kelp species, and species correlated with (E-H) PCA1, (I-L) PCA2, and (M-P) PCA3

Macroalgae were more likely to be abundant at shallower depths, with some species more abundant in wave shelter, such as the kelp Saccharina latissima (Fig. 3A), some more abundant in intermediate wave exposure such as Saccorhiza polyschides (Fig. 3B), and others more abundant in moderate to strong wave exposure (Fig. 3D-G). Suspension feeders had a wider variety of distributions along wave and depth gradients, from deeper water in places with more shelter from waves (Ciona intestinalis, Fig. 3J; also Ascidia mentula, not shown) to shallow water in wave-exposed habitats, often associated with Laminaria hyperborea (Membranipora membranacea, Obelia geniculata, Halichondria panacea, Electra pilosa). Grazers and predators had a similar variety of patterns, including the 'sit-and-wait' predators Urticina felina and Sagartia elegans (Fig. 3O,P), which were most abundant in extreme wave exposure. The 
urchin Echinus esculentus was abundant across a range of wave exposures but more so $>10 \mathrm{~m}$ depth, and Gibbula cineraria was abundant in $<5-10 \mathrm{~m}$ in moderate exposure.

Twenty-three out of 25 species of macroalgae were negatively related to chl a (Table S2, Fig. 4; chisquared test of expected 1:1 ratio of positive and negative values $\mathrm{p}<0.001$ ), but suspension feeders, grazers and predators were otherwise fairly evenly divided between those positively and negatively associated with chl a. Macroalgae mostly increased with tidal power (20 of 25 species), but there was no clear tendency in the other functional groups. The interactive effects of tide and chl a were associated with the effect of chl a on species (Fig. 4B): the magnitude of both negative and positive effects of chl a were generally amplified by increasing tidal flow. This amplification was especially marked in macro- algae, with 22 out of 25 species having a negative interaction of tidal flow and chl a. For example, the negative influence of $\mathrm{chl}$ a on the red alga Bonnemaisonia asparagoides (Fig. 4C) and the positive influence of chl a on the starfish Asterias rubens (Fig. 4D) are both more pronounced in high than in low tidal flow.

\section{Community patterns and species associations: PCA results}

The first principal component (PCA1) explained $11.0 \%$ of the total variance. PCA2 explained $5.7 \%$, PCA3 explained $4.3 \%$, and PCA4 explained $3.2 \%$ of the total variance, and only the first 3 components were considered further in analyses. PCA1 was most strongly correlated with the abundance of the kelp
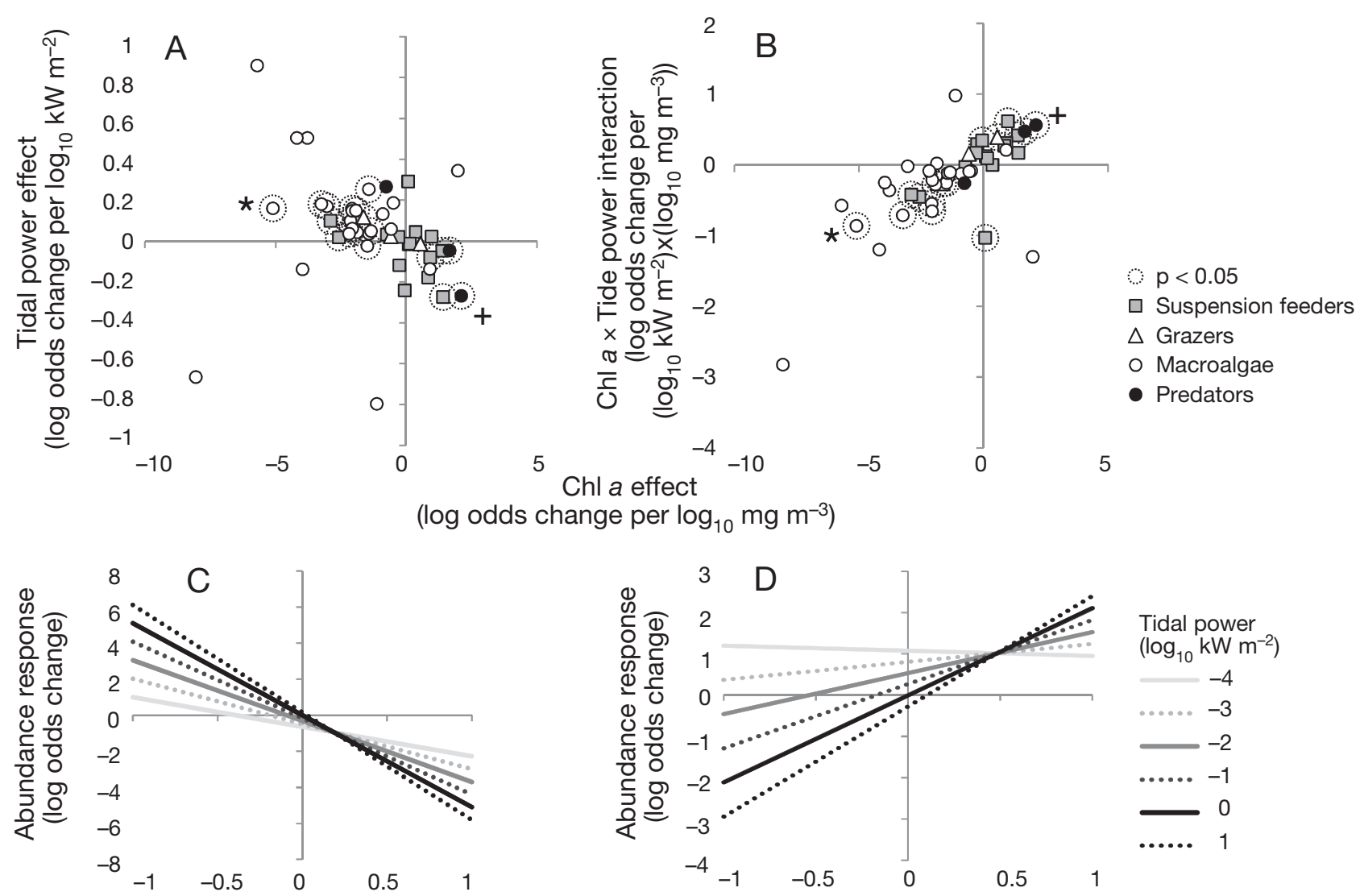

Chl a $\left(\log _{10} \mathrm{mg} \mathrm{m}^{-3}\right)$

Fig. 4. The interdependence of (A) chl $a$ and tidal power effects and (B) Chl $a \times$ Tide interaction and chl $a$ effects on the likelihood of species abundance categories, expressed as linear parameters from ordinal logistic regression. Each point shows the response of a single species, with symbols denoting functional groups. Tidal influence is weakly negatively correlated with chl a influence (Panel A, $\mathrm{r}=-0.200$ ), but the Chl $a \times$ Tide interaction is strongly correlated with chl $a$ influence (Panel B, $\mathrm{r}=0.671, \mathrm{n}=46$ species). Data are given in Table S2 in the supplement at www.int-res.com/articles/suppl/m445p193 _supp.pdf. Responses to chl a at different levels of tidal power are shown for (C) the red alga Bonnemaisonia asparagoides (indicated by ' $*$ ' in Panels A \& B) and (D) the starfish Asterias rubens (indicated by ' + ' in panels A \& B) 
Laminaria hyperborea (Lahyp; Fig. 5), the red algae Plocamium cartilagineum, Cryptopleura ramosa, Dictyota dichotoma and Phycodrys rubens, and the molluscan grazers Gibbula cineraria and Calliostoma zizyphinum (Plcar, Crram, Didic, Phrub, Gicin, Caziz; Fig. 5). Most importantly PCA1 correlated very strongly with the total number of species recorded in the survey $(\mathrm{r}=0.92$, no. species $=7.22+4.89 \times$ PCA1, $\left.\mathrm{R}^{2}=0.84\right)$. The second principal component correlated negatively with 21 of the 25 macroalgae, albeit with r near zero in 8 species, and positively with the urchin Echinus esculentus (Ecesc; Fig. 5) and a group of 9 suspension feeders that included all 4 tunicate species (Ascidia mentula [Asmen], Ascidiella aspersa [Asasp], Ciona intestinalis [Ciint], and Clavelina lepadiformis [Cllep]; Fig. 5), the feather star Antedon bifida (Anbif), the tubeworm Pomatoceros triqueter (Potri) and the sponge Alcyonium digitatum (Aldig).

PCA3 correlated negatively with those species normally found in wave-sheltered areas, such as the kelps Saccharina latissima (Salat) and Saccorhiza polyschides (Sapol), and correlated positively with species from wave-swept conditions, the anemones Urticina felina (Urfel) and Sagartia elegans (Saele), and the sponge Alcyonium digitatum (see Table S2).

\section{Patterns of PCA scores and diversity among fetch and depth classes}

PCA scores and the number of species per survey showed significant patterns among the 6 regions and across gradients of depth and wave fetch (Figs. 6 \& 7). The magnitude of variance estimates for terms in the ANOVA models indicates the relative importance of regional differences and the depth and wave fetch gradients (Table 1). PCA1 was most strongly correlated with Laminaria hyperborea and species diversity, had highest values in shallow water $(<10 \mathrm{~m})$ in areas of greatest wave fetch $\left(>3 \log _{10}\right.$ cells; Fig. 6A), and was similarly influenced by wave fetch and depth (Table 1). In contrast, PCA2 was more affected by depth than wave fetch. PCA2 had lowest values in shallowest depths ( $<5 \mathrm{~m}_{i}$ Fig. $\left.6 \mathrm{~B}\right)$ and highest values in $>10 \mathrm{~m}$ depth, representing a change from macroalgae-dominated to animal-dominated communities with depth. High PCA2 values extended deeper in extreme wave exposure $\left(\geq 4 \log _{10}\right.$ cells; Fig. 6B). Values of PCA3 were much more influenced by wave fetch than depth (Fig. 6C), consistent with the strong correlation between PCA3 scores and the abundance of anemones typical of wave-exposed conditions (Urticina felina and Sagartia elegans).

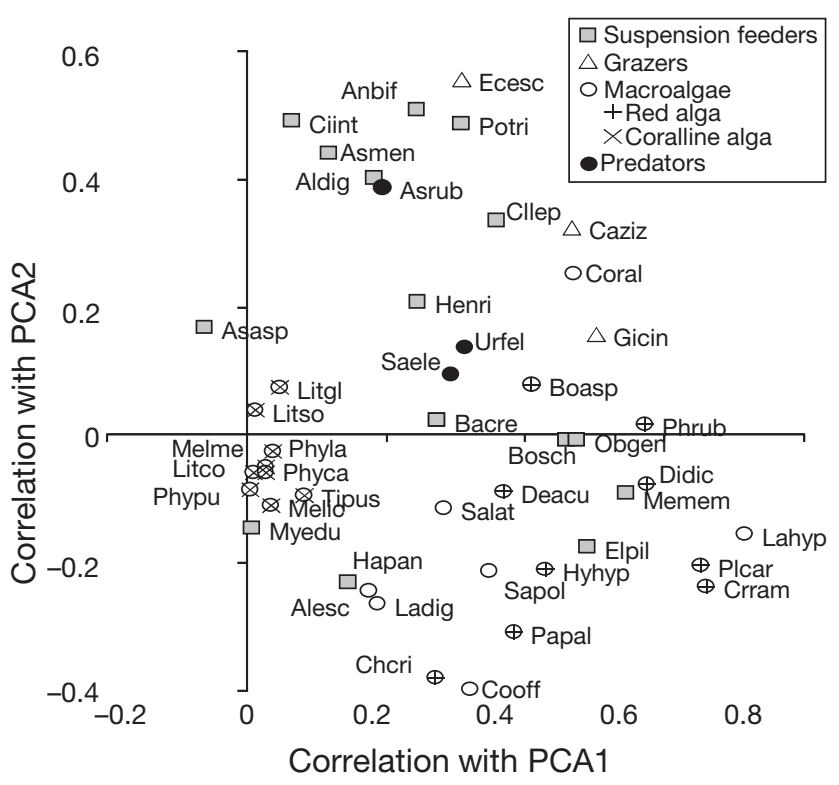

Fig. 5. Correlations of the abundance scores of species in the PCA analysis with the first 2 principal component scores, shown as a scatter plot with symbols indicating functional groups and morphological types of macroalgae. Abbreviations as in Table S2 in the supplement

PCA4 (Fig. 6D) was similar to PCA3, with highest values found in wave shelter $\left(<2.5 \log _{10}\right.$ cells $)$. Given the strong correlation between PCA1 and species diversity, it was not surprising that the number of species was greater in more wave exposed and shallower areas (Fig. 6D).

Region effects were of a similar magnitude to those of depth and wave fetch (Table 1). PCA1 (Fig. 7B,F) and species diversity (Fig. 7A,E) were higher in Scotland and the Irish Sea than in SW England, and least in the North Sea (E England). PCA2 was highest in NW Scotland and lowest in SW and E England (Fig. 7C,G). PCA3 was associated, in particular, with species from wave-exposed habitats and was highest in the Irish Sea, intermediate in SW and E England, and lowest in Scotland (Fig. 7D,H). In general, patterns of community structure along depth and wave fetch gradients were similar in the different regions, with significant Region $\times$ Depth and Region $\times$ Fetch interactions having only minor modifying effects on the patterns.

\section{Effects of ocean colour and tidal flow on PCA scores and diversity}

PCA1, associated with Laminaria hyperborea and species diversity, declined with chl a (Table 1), and the effect was most pronounced at $5 \mathrm{~m}$ depth (Fig. 7I) 

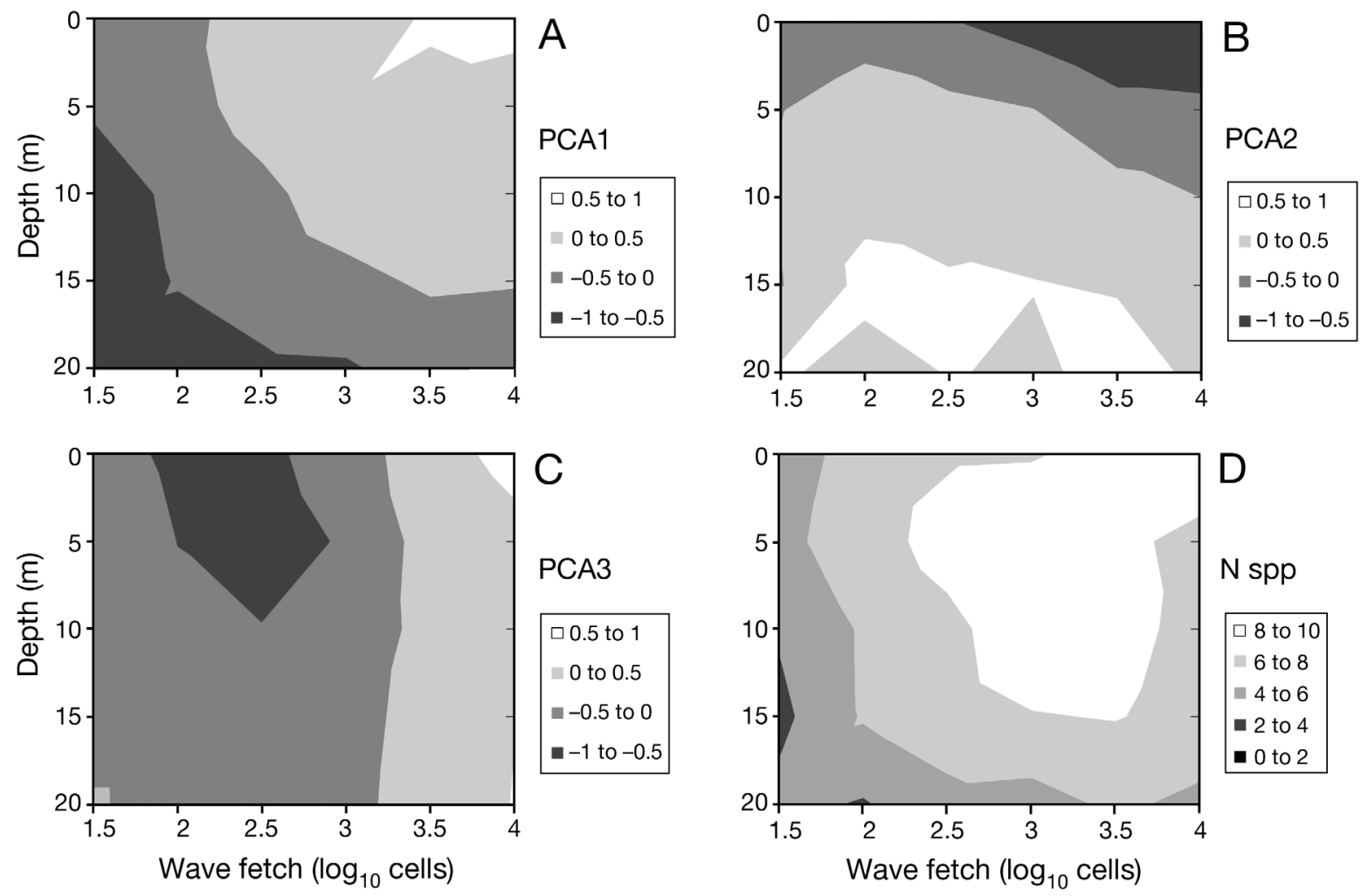

Fig. 6. Patterns of mean values of (A) PCA1, (B) PCA2, (C) PCA3, and (D) number of species (N spp), among depth and wave fetch classes as $2 \mathrm{D}$ surface plots

and in the greatest wave exposure (Fig. 7J). The response of PCA2, which represented the shift from macroalgae to filter feeders, to chl a was modified by tidal flow, as indicated by the significant interaction term (Chl $a \times$ Tide effect; Table 1). PCA2 increased with tidal flow in areas of high chl a (1.5) but did not change with flow in areas of lower chl a concentrations (0.5), and thus PCA2 increased with chl $a$ in high, but not low, flow. PCA3, which represented the shift from wave-sheltered species like Saccharina latissima to exposed species like Urticina felina, also showed changing responses to tide and chl a modified by the level of the other variable ( $\mathrm{Chl} a \times$ Tide effect; Table 1). PCA3 increased with tidal flow at high chl a (1.5) but did not change with flow at low chl $a(0.5)$ and, similarly, decreased with chl $a$ in low flow $(-5)$ and did not change in high flow (-1). Highest values for PCA3 were in high flow across all chl a values, and lowest values were in low flow and high chl a. Positive responses of PCA3 to chl a were strongest in shallow water $(0-5 \mathrm{~m}$; Fig. 7I) and in wave exposed conditions $\left(3.5 \log _{10}\right.$ cells; Fig. $\left.7 \mathrm{~J}\right)$, while positive responses to tidal flow were strongest at greatest depths (>15 m; Fig. 7K).

The strong association of species diversity with PCA1 scores and Laminaria hyperborea abundance suggested that this kelp species was the main influence on patterns of species diversity on UK coastlines. Laminaria hyperborea cover explained $47 \%$ of the variance in species diversity among sites (Fig. 8A; $\mathrm{R}^{2}=0.47$, 1-way ANOVA of total number of species versus maximum percentage cover for 3307 sites, $\mathrm{p}<<0.001$ ). Sites without L. hyperborea had a median of only 6 species, while those with over $40 \%$ cover had nearly 4 times as many, with a median of 22 species. Other kelp species also positively influenced diversity, such as Saccharina latissima $\left(\mathrm{R}^{2}=\right.$ $0.18)$, Saccorhiza polyschides $\left(\mathrm{R}^{2}=0.13\right)$ and L. digitata $\left(\mathrm{R}^{2}=0.04\right)$, but to a much lesser degree. Laminaria hyperborea was present at $36 \%$ of all sites and in all regions ( $28-49 \%$ of sites in each region). Saccharina latissima was similarly prevalent $(36 \%$ of all sites, $12-58 \%$ in regions), while Saccorhiza polyschides was less frequently recorded $(11 \%$ of all sites, $3-22 \%$ in regions).

Trends in species diversity in rocky subtidal areas may thus be mostly driven by those factors influencing the distribution of Laminaria hyperborea. This can be shown by a structural equation model (Fig. 8B; Shipley 2000) of the proposed relationships among the variables. For this causal structure it can be seen that while wave exposure and tidal flow are 

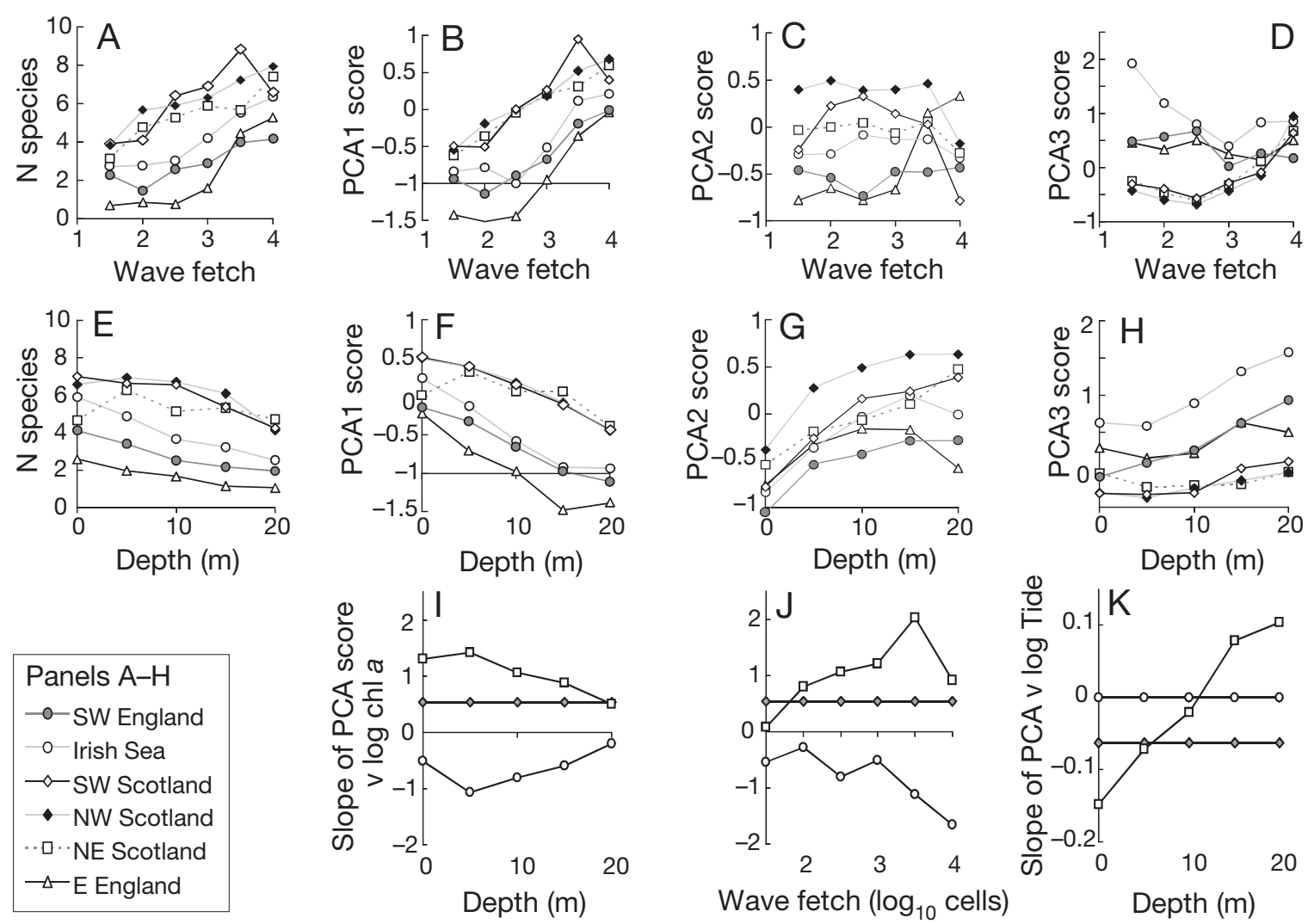

Panels I-K
$-0-$ PCA1
$\multimap-$ PCA2
$-\square-$ PCA3

Fig. 7. Regional average values of number of species ( $\mathrm{N}$ species) per survey and factor scores from principal components analysis of community data (PCA1 to PCA3) by (A-D) wave fetch classes and (E-H) depth classes. Responses of PCA1 and PCA3 to chl a depended on (I) depth and (J) wave fetch, while the response of PCA3 to tidal power depended on (K) depth

strongly correlated, exposure and wave fetch determine L. hyperborea distribution. Species diversity appears not to be directly influenced by waves, flow and chl $a$, but indirectly through their effects on the dominant species of kelp in the area.

\section{DISCUSSION}

Mapping wave fetch allows us to better assess local habitat characteristics relative to larger scale factors as influences on community assemblages. Wave motion modifies responses to changes in ocean colour, for example the shift from macroalgae to suspension feeders is more pronounced in areas of greater wave exposure.

The most striking pattern emerging from the analysis was that the primary source of variation in community composition and species diversity was the abundance of the dominant habitat-forming kelp species Laminaria hyperborea, which was present at over a third of sites and across all regions. Kelp is well known to support diverse assemblages (Christie et al. 2003, 2009) so it is perhaps unsurprising that sites with $>40 \%$ cover of $L$. hyperborea had nearly 4 times as many species as sites without L. hyperborea. Removal of this species by harvesting reduces gadoid fish abundance and the use of habitats by diving cormorants (Lorentsen et al. 2010), and will also have a major impact on species diversity. The preliminary structural equation model (Fig. 8B) gives further evidence for L. hyperborea cover, rather than light and waves, as a direct cause of species diversity: light attenuation (as chl a) and wave exposure influence $L$. hyperborea abundance and this in turn drives diversity. Laminaria hyperborea acts as an ecosystem engineer (Jones et al. 1994). Besides providing specific habitats for epibionts - the frond for bryozoa (Membranipora membranacea, Electra pilosa) (Schultze et al. 1990) and hydroids (Obelia geniculata), the stipe for algae such as Phycodrys rubens (Kain 1960) and the holdfast for polychaetes and amphipods (Moore 1986)-large kelp plants modify their immediate environment in a positive way. Light levels are reduced beneath the kelp canopy creating conditions suitable for dim-light 


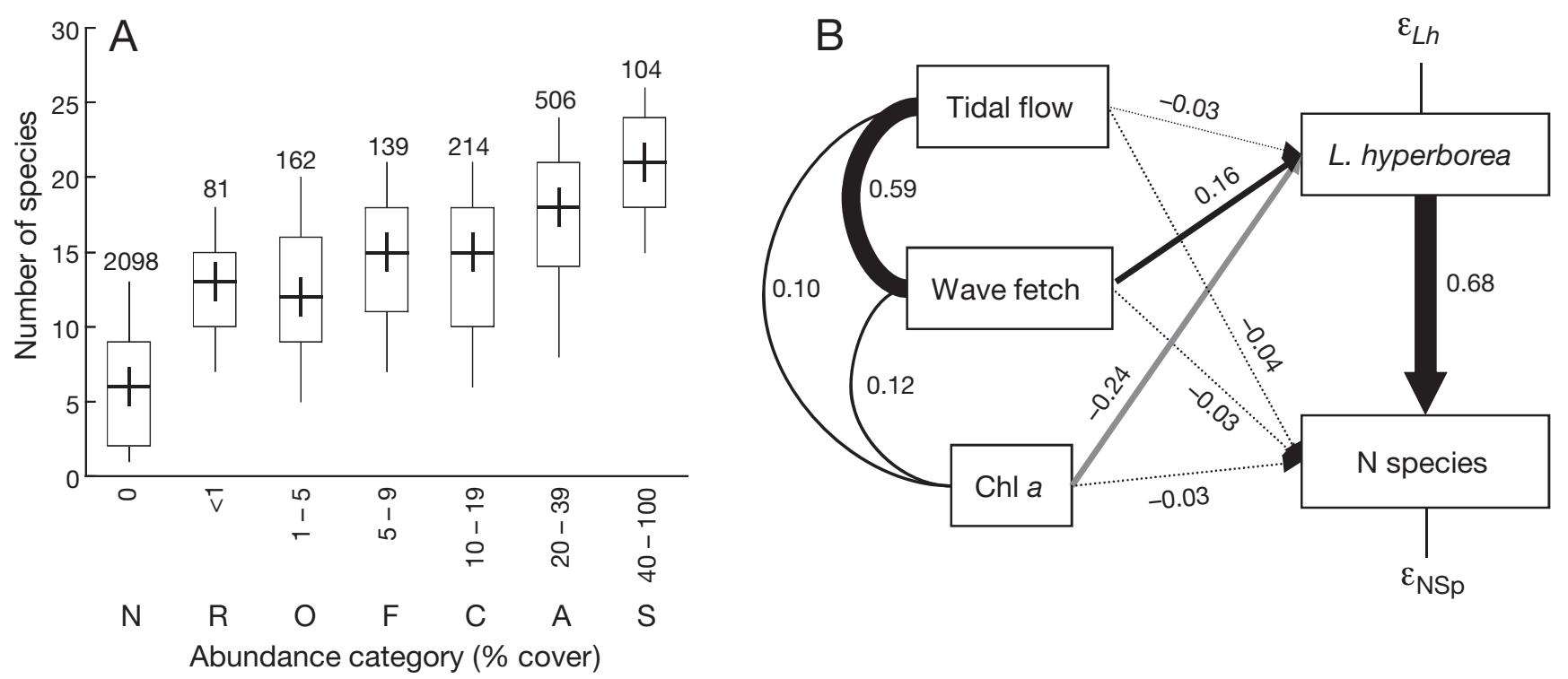

Fig. 8. Laminaria hyperborea. (A) Number of species recorded across all depths at a site (cross, median; box, 25th-75th percentiles; whiskers, 10th and 90th percentiles) versus the maximum recorded percentage cover of kelp as abundance categories ( $N$, absent; $R$, rare; O, occasional; F, frequent; $C$, common; A, abundant; $S$, superabundant). Numbers above boxes show number of surveys in each category. (B) A structural equation model of the main factors affecting species diversity in the UK rocky subtidal. Unconstrained error terms were included in the model for kelp abundance and number of species $\left(\varepsilon_{L h}\right.$ and $\varepsilon_{N S p}$, respectively). Values shown are standardised regression weights. Dotted paths show weights with $\mathrm{p}>0.01$

tolerant understorey algae (Kennelly 1987), such as Cryptopleura ramosa and Dictyota dichotoma. Reduced water flow speeds under kelp canopies may increase the settlement of particulate organic material, favouring the growth of (active) suspension feeders such as sponges and ascidians (Wildish \& Kristmanson 1997).

Light is well known as the main influence on the distribution, depth and abundance of kelp (see Kain 1979 for review, Dayton 1985), so it is not surprising that satellite-sensed chl a concentration was the main negative influence on Laminaria hyperborea and hence diversity. Increased phytoplankton content in oceanic waters and increased suspended and dissolved terrestrial material in coastal waters are both associated with greater light attenuation, irrespective of whether calculated chl a concentration is a true reflection of phytoplankton. Greater attenuation results in reduced depth penetration of kelp communities. In the UK, for example, the lower limit of kelp and foliose algae increased up the Bristol Channel towards the mouth of the Severn, along a gradient of increasing turbidity (Hiscock 1985). With L. hyperborea kelp as the main driver of species diversity, increased phytoplankton concentrations through eutrophication and increased sediment in the water are major threats to biodiversity on subtidal rock. Longterm changes in the extent and abundance of kelp forests reflect these processes, such as the impact of the San Diego sewage outfall on the Point Loma Macrocystis pyrifera forest and its recovery following the construction of an offshore outfall bypassing the kelp forest in 1963 (Tegner et al. 1996).

Principal components analysis as a method of reducing the dimensionality of complex community data has its advantages and disadvantages over other approaches, such as multidimensional scaling (Legendre \& Legendre 1998), but does reveal species associations in a relatively rapid way and allows the association of groups of species with environmental variables to be addressed with statistical models. The other axes of change, from macroalgae to suspension feeders (PCA2) and from wave-sheltered species such as the sugar kelp Saccharina latissima, to waveexposed species (PCA3) such as (passive) suspension-feeding anemones Sagartia elegans and Urticina felina, reflect the major changes in species assemblages along gradients of depth and wave exposure.

Habitat preferences of these species are relatively well known, such as the replacement of shelteredwater kelp Saccorhiza polyschides by Laminaria hyperborea in greater wave exposure, and the association of $L$. digitata with shallow water (Kain 1979). An ability to map wave exposure, tidal flow and light attenuation, allows better understanding of associations and interactions among the effects of the under- 
lying factors and identification of potential mechanisms behind these community and species level changes. This further allows separation of regional and local scale effects and determination of whether regional differences are a consequence of regional changes in ocean colour, wave fetch and tidal flow, rather than changes in the fundamental pool of species.

The otherwise depth-related shift from dominance by macroalgae to suspension feeders (PCA2) was more pronounced in areas of combined high chl a and high tidal flow. It seems likely that the negative effect of greater light attenuation on benthic macroalgae in high chl a may be supplemented by a positive effect for suspension feeders of a greater food supply as a result of a greater food concentration and a greater flow, as well as any potential competition for space between algae and suspension feeders. Effects of chl a concentration were amplified in high flow rates. Food concentration and flow rate often combine to produce faster growth in suspension feeders (Sanford et al. 1994, Witman et al. 2004, Burrows et al. 2010), though growth can be reduced at extreme flow rates. Increased performance by suspension feeders is associated with a shift in dominance from primary producers to suspension feeders (Leonard et al. 1998), also seen in the intertidal in areas of higher chl a associated with local upwelling in on the Pacific coast of North America (Menge et al. 2003, 2004), enhanced nutrients in the UK (Burrows et al. 2008), and potentially the shift from rockweed to mussel-dominated communities in Maine estuaries (Petraitis \& Latham 1999, Bertness et al. 2002).

The mechanisms driving the inverse relationship between macroalgae and microalgae abundance may not be unidirectional. Macroalgae compete for nutrients with microalgae, and the former may reduce or alter assemblages of the latter (Fong et al. 1993). This may be particularly evident in sheltered rocky areas and may allow kelp to persist in areas where high nutrients may otherwise produce a shading effect from a dense phytoplankton community.

Thus far, explanations of the emerging patterns of species and assemblages have not needed to invoke strong species interactions for replacement of one group by another. Given the primacy of kelp in structuring the observed communities, there was little obvious evidence for the replacement of Laminaria hyperborea forests with urchin barrens. The most abundant urchin, Echinus esculentus, was positively associated with suspension feeders and negatively associated with macroalgae, but this appeared to be related to a shift from shallow to deeper habitat rather than a change from a heavily to a lightly grazed community.

In terms of trophic structuring and the dominant direction of trophic control, either bottom-up or topdown (or donor- versus recipient-control; Polis \& Strong 1996), the predominant class of proposed mechanisms appears to be bottom-up. Enhanced food supply promotes suspension feeders, light limitation limits primary producers, and wave-induced water motion modifies the response to food supply and is associated with a shift to more robust species. The first two of these mechanisms depend critically on processes in the overlying water. The coupling between pelagic and benthic systems appears to be particularly strong in these subtidal communities. Unlike intertidal areas in upwelling systems, the primary mechanism appears not to be limitation of the supply of larvae of suspension feeders (e.g. Navarrete et al. 2005), but rather a combination of shading and food supply by the pelagic to the benthic assemblages.

Acknowledgements. This work was funded by the UK Natural Environment Research Council as part of the Oceans 2025 Biodiversity Theme at the Scottish Association for Marine Science. We thank JNCC for making the MNCR data fully publicly available and NOAA/NASA for making satellite ocean colour available via the Giovanni online data system, developed and maintained by the NASA GES DISC.

\section{LITERATURE CITED}

ABP Marine Environmental Research (2008) Atlas of UK Marine Renewable Energy Resources: Technical Report R.1432, ABP Marine Environmental Research. www. renewables-atlas.info/downloads/documents/R1432_Final _15May08.pdf (Accessed 27 Jan 2010)

Arbuckle J (2005) Amos 6.0 User's Guide. Marketing Department, SPSS Inc. and Amos Development Corporation

Ballantine WJ (1961) A biologically-defined exposure scale for the comparative description of rocky shores. Field Stud 1:1-19

Baardseth E (1970) A square-scanning, two-stage sampling method of estimating seaweed quantities. Rep Norw Inst Seaweed Res 33:1-41

Bekkby T, Isachsen PE, Isæus M, Bakkestuen V (2008) GIS Modeling of wave exposure at the seabed: a depth-attenuated wave exposure model. Mar Geod 31:117-127

Bekkby T, Rinde E, Erikstad L, Bakkestuen V (2009) Spatial predictive distribution modelling of the kelp species Laminaria hyperborea. ICES J Mar Sci 66:2106-2115

BERR (2008) Atlas of UK Marine Renewable Energy Resources: Tidal. Department for Business, Enterprise and Regulatory Reform. www.renewables-atlas.info/ (Accessed 27 Jan 2010)

Bertness MD, Trussell GC, Ewanchiuk PJ, Silliman BR (2002) Do alternative stable states exist in the Maine rocky intertidal zone? Ecology 83:3434-3448

Birkett DA, Maggs CA, Dring MJ, Boaden PJS, Seed R 
(1998) Infralittoral reef biotopes with kelp species, Vol 7. An overview of dynamics and sensitivity characteristics for conservation management of marine SACs. Scottish Association for Marine Science, UK Marine SACs Project

Booij N, Ris RC, Holthuijsen LH (1999) A third-generation wave model for coastal regions 1. Model description and validation. J Geophys Res 104:7649-7666

Burrows MT, Harvey R, Robb L (2008) Wave exposure indices from digital coastlines and the prediction of rocky shore community structure. Mar Ecol Prog Ser 353:1-12

Burrows MT, Jenkins SR, Robb L, Harvey R (2010) Spatial variation in size and density of adult and post-settlement Semibalanus balanoides: effects of oceanographic and local conditions. Mar Ecol Prog Ser 398:207-219

> Christie H, Jørgensen NM, Norderhaug KM, Waage-Nielsen E (2003) Species distribution and habitat exploitation of fauna associated with kelp (Laminaria hyperborea) along the Norwegian coast. J Mar Biol Assoc UK 83:687-699

Christie H, Norderhaug KM, Fredriksen S (2009) Macrophytes as habitat for fauna. Mar Ecol Prog Ser 396: 221-233

Connor DW, Hiscock K (1996) Data collection methods. In: Hiscock K (ed) Marine Nature Conservation Review: rationale and methods. Joint Nature Conservation Committee, Peterborough, p 51-65

Connor DW, Allen JH, Golding N, Howell KL, Lieberknecht LM, Northen KO, Reker JB (2004) The marine habitat classification for Britain and Ireland, version 04.05. Joint Nature Conservation Committee, Peterborough

Cotton AD (1909) Marine algae of the west of Ireland. Kew Bull Misc Inform 1909:312-315

> Crothers JH (1983) Variation in dogwhelk shells in relation to wave action and crab predation. Biol J Linn Soc Lond 20:85-102

Crowder L, Norse E (2008) Essential ecological insights for marine ecosystem-based management and marine spatial planning. Mar Policy 32:772-778

> Davies AJ, Johnson MP (2006) Coastline configuration disrupts the effects of large-scale climatic forcing, leading to divergent temporal trends in wave exposure. Estuar Coast Shelf Sci 69:643-648

> Dayton PK (1985) Ecology of kelp communities. Annu Rev Ecol Syst 16:215-245

Denny MW (1988) Biology and the mechanics of the waveswept environment. Princeton University Press, Princeton, NJ

> Fong P, Donohoe RM, Zedler JB (1993) Competition with macroalgae and benthic cyanobacterial mats limits phytoplankton abundance in experimental microcosms. Mar Ecol Prog Ser 100:97-102

> Friedland MT, Denny MW (1995) Surviving hydrodynamic forces in a wave-swept environment-consequences of morphology in the feather boa kelp, Egregia menziesii (Turner). J Exp Mar Biol Ecol 190:109-133

Harborne AR, Mumby PJ, Zychaluk K, Hedley JD, Blackwell PG (2006) Modeling the beta diversity of coral reefs. Ecology 87:2871-2881

Hiscock K (1985) Aspects of the ecology of rocky sublittoral areas. In: Moore PG, Seed R (eds) Ecology of rocky coasts. Hodder \& Stoughton, London, p 290-328

Hiscock K (ed) (1996) Marine nature conservation review: rationale and methods. Joint Nature Conservation Committee, Peterborough

Isaeus M (2004) Factors structuring Fucus communities at open and complex coastlines in the Baltic Sea. PhD thesis, Stockholm University

> Jones WE, Demetropoulos A (1968) Exposure to wave action: measurements of an important ecological parameter on rocky shores on Anglesey. J Exp Mar Biol Ecol $2: 46-63$

Jones C, Lawton J, Shachak M (1994) Organisms as ecosystem engineers. Oikos 69:373-386

Jonsson PR, Granhag L, Moschella PS, Aberg P, Hawkins SJ, Thompson RC (2006) Interactions between wave action and grazing control the distribution of intertidal macroalgae. Ecology 87:1169-1178

- Kain J (1960) Direct observations on some Manx sublittoral algae. J Mar Biol Assoc UK 39:609-630

- Kain JM (1977) The biology of Laminaria hyperborea. X. The effect of depth on some populations. J Mar Biol Assoc UK 57:587-607

Kain JM (1979) A view of the genus Laminaria. Oceanogr Mar Biol Annu Rev 17:101-161

Kennelly S (1987) Physical disturbances in an Australian kelp community. II. Effects on understorey species due to differences in kelp cover. Mar Ecol Prog Ser 40:155-165

Legendre P, Legendre L (1998) Numerical ecology. Elsevier, New York, NY

Leonard GH, Levine JM, Schmidt PR, Bertness MD (1998) Flow-driven variation in intertidal community structure in a Maine estuary. Ecology 79:1395-1411

Lewis JR (1964) The ecology of rocky shores. English Universities Press, London

> Lorentsen SH, Sjøtun K, Grémillet D (2010) Multi-trophic consequences of kelp harvest. Biol Conserv 143: 2054-2062

Mach KJ, Hale BB, Denny MW, Nelson DV (2007) Death by small forces: a fracture and fatigue analysis of waveswept macroalgae. J Exp Biol 210:2231-2243

> Menge BA, Sutherland JP (1987) Community regulation: variation in disturbance, competition, and predation in relation to environmental stress and recruitment. Am Nat 130:730-757

Menge BA, Lubchenco J, Bracken MES, Chan F and others (2003) Coastal oceanography sets the pace of rocky intertidal community dynamics. Proc Natl Acad Sci USA 100: 12229-12234

> Menge BA, Blanchette C, Raimondi P, Freidenburg T and others (2004) Species interaction strength: testing model predictions along an upwelling gradient. Ecol Monogr 74:663-684

Moore P (1985) Levels of heterogeneity and the amphipod fauna of kelp holdfasts. In: Moore PG, Seed R (eds) The ecology of rocky coasts. Hodder \& Stoughton, London, p 274-289

NASA (2009) MODIS Aqua Chlorophyll a concentration. http://disc.sci.gsfc.nasa.gov/giovanni/ (Accessed 9 Jul 2009)

Navarrete SA, Wieters EA, Broitman BR, Castilla JC (2005) Scales of benthic-pelagic coupling and the intensity of species interactions: from recruitment limitation to topdown control. Proc Natl Acad Sci USA 102:18046-18051

NBN (2006) UK National Biodiversity Network NBN Gateway. http://data.nbn.org.uk/ (Accessed 9 Oct 2006)

NOAA (2007) GSHHS - A Global Self-consistent, Hierarchical, High-resolution Shoreline Database. www.ngdc.noaa. gov/mgg/shorelines/gshhs.html (Accessed 11 Oct 2007)

Pepper A, Puotinen ML (2009) GREMO: A GIS-based generic model for estimating relative wave exposure. In: Anderssen RS, Braddock RD, Newham LTH (eds) Inter- 
facing modelling and simulation with mathematical and computational sciences. 18th World IMACS / MODSIM Congress, Cairns, Australia, 13-17 July 2009

Petraitis PS, Latham RE (1999) The importance of scale in testing the origins of alternative community states. Ecology 80:429-442

Polis GA, Strong DR (1996) Food web complexity and community dynamics. Am Nat 147:813-846

Sanford E, Bermudez D, Bertness MD, Gaines SD (1994) Flow, food supply and acorn barnacle population dynamics. Mar Ecol Prog Ser 104:49-62

SAS Institute (2004) SAS 9.1.3 help and documentation. SAS Institute, Cary, NC

Schultze K, Janke K, Krüß A, Weidemann W (1990) The macrofauna and macroflora associated with Laminaria digitata and L. hyperborea at the island of Helgoland (German Bight, North Sea). Helgol Mar Res 44:39-51

Shanks AL, Wright WG (1986) Adding teeth to wave action: the destructive effects of wave borne rocks on intertidal organisms. Oecologia 69:420-428

Shipley B (2000) Cause and correlation in biology: a user's guide to path analysis, structural equations and causal inference. Cambridge University Press, Cambridge

Sjøtun K, Fredriksen S (1995) Growth allocation in Lami-

Editorial responsibility: Laura Airoldi,

Ravenna, Italy naria hyperborea (Laminariales, Phaeophyceae) in relation to age and wave exposure. Mar Ecol Prog Ser 126: 213-222

Sokal RR, Rohlf FJ (1996) Biometry, 3rd edn. WH Freeman, New York, NY

Steneck RS, Dethier MN (1994) A functional group approach to the structure of algal-dominated communities. Oikos 69:476-498

Tegner MJ, Dayton PK, Edwards PB, Riser KL (1996) Is there evidence for long-term climatic change in southern California kelp forests? Calif Coop Oceanic Fish Invest Rep 37:111-126

Thomas MLH (1986) A physically derived exposure index for marine shorelines. Ophelia 25:1-13

Vadas RL, Wright WA, Miller SL (1990) Recruitment of Ascophyllum nodosum: wave action as a source of mortality. Mar Ecol Prog Ser 61:263-272

Wildish D, Kristmanson DD (1997) Benthic suspension feeders and flow. Cambridge University Press, Cambridge

Witman JD, Patterson MR, Genovese SJ (2004) Benthicpelagic linkages in subtidal communities: the influence of food subsidies by internal waves. In: Polis GA, Powers ME, Huxel GR (eds) Food webs at the landscape level. University of Chicago Press, Chicago, IL, p 133-153

Submitted: January 21, 2011; Accepted: September 26, 2011 Proofs received from author(s): January 10, 2012 